\title{
INTERVENSI KOMUNITAS “RIFKA ANNISA” YOGYAKARTA PADA PEREMPUAN KORBAN KEKERASAN DALAM RUMAH TANGGA
}

\author{
Indrawati \\ STID Al-Hadid, Surabaya \\ Indrawati210275@gmail.com
}

\author{
Sukma Paramastuti \\ STID Al-Hadid, Surabaya \\ Sukimaparamas@gmail.com
}

\begin{abstract}
Abstrak: Tulisan ini dilatarbelakangi oleh adanya fenomena kekerasan dalam rumah tangga (KDRT) yang korbannya sebagian besar adalah perempuan (istri) dengan pelakunya adalah laki-laki (suami). Penanganan kasus KDRT telah banyak diinisiasi oleh lembaga swadaya masyarakat (LSM) yang concern terhadap pendampingan perempuan korban KDRT, salah satunya adalah Rifka Annisa Yogyakarta. Fokus tulisan ini mengkaji model intervensi komunitas dalam menangani perempuan korban KDRT di Yogyakarta. Metode pengkajian tulisan ini menggunakan metode library research. Dengan menggunakan teori model intervensi komunitas Rothman dan Tropman, studi ini menyimpulkan bahwa model intervensi komunitas yang dilakukan oleh Rifka Annisa cenderung menggunakan model perencanaan sosial dalam menangani perempuan korban KDRT, namun selain itu ditemukan juga model pengembangan masyarakat lokal dalam usaha membangun kesadaran para laki-laki agar peduli dengan pasangan lewat program meeting couple dan pendirian Komunitas Laki-laki Peduli sebagai usaha mencegah KDRT sejak dini, termasuk usaha pengorganisasian masyarakat sebagai elemen sosial yang paling dekat dengan peristiwa KDRT yang berfungsi sebagai sumber pencegah dan penanganan KDRT sejak dini lewat pendirian CBCC (Community Based Crisis Center), terakhir model aksi sosial ditemukan juga lewat usaha Rifka Annisa dalam menggawangi UndangUndang yang bertujuan mengeliminasi kekerasan dan pelayanan terhadap perempuan korban kekerasan dalam rumah tangga.

Kata Kunci: model intervensi komunitas, perempuan, kekerasan dalam rumah tangga
\end{abstract}

Community Intervention of "Rifka Annisa” Yogyakarta Towards Woman Victims of Domestic Violance. Abstract: This paper was grounded by domestic violence phenomena most of whose victims are women (wives) and perpetrators are men (their husbands). The treatment for domestic violence cases has been initiated by non-government organizations concerning on counselling the woman victims of domestic violence. One of them is Rifka Annisa - Yogyakarta. This paper focuses on studying model of community intervention on assisting woman victims of domestic violence in Yogyakarta. It applies library research method and uses the theory of Rothman and Tropman's Community Intervention Model. This study concludes that community intervention model conducted by Rifka Annisa tends to apply Social Planning Model on treating the victims. In addition, Model of Locality Development Model is found in improving men's awareness towards their spouses through Meeting Couple program and the establishment of Komunitas Laki-laki Peduli as an effort to avoid domestic violence in early stage, and organizing community as the nearest social element from domestic violence functioning as a preventive and assisting source of domestic violence through CBCC (Community Based Crisis Center). At last, Social Action model is found in passing the laws aiming to eliminate such violences and improve service towards woman victims of domestic violence.

Keywords: Community intervention model, woman victims, domestic violence 


\section{Pendahuluan}

Kekerasan terhadap perempuan dan anak telah menjadi perhatian hampir di seluruh negara, baik di negara berkembang maupun di negara maju. Beberapa badan dunia dan lembaga nonpemerintah yang concern dengan masalah kekerasan terhadap perempuan dan anak sampai kini terus menyuarakan untuk mengakhiri kekerasan tersebut. Berbagai program dan kebijakan terkait perlindungan terhadap perempuan dan anak terus didorong untuk dilaksanakan di seluruh negara. Bahkan Tujuan Pembangunan Berkelanjutan (Sustainable Development Goals/SDGs) secara khusus memasukkan aspek mengakhiri kekerasan terhadap perempuan dan anak menjadi target yang harus dicapai pada tahun 2030 . Berbagai tindak kekerasan dalam rumah tangga seringkali menjadikan pihak perempuan (istri) menjadi korban dari suaminya. Tercatat oleh UNICEF, ${ }^{1}$ bahwa perilaku KDRT yang dilakukan oleh pihak suami bentuknya bisa kekerasan secara fisik, psikis, maupun ekonomi. Berdasarkan data yang dimiliki Woman Crisis Centre Rifka Annisa, tercatat jumlah perempuan korban KDRT yang melapor di Yogyakarta pada kurun waktu tahun 2009-2016 adalah sekitar 1.757 orang, sehingga ada sekitar 250 orang perempuan di Yogyakarta yang menjadi korban KDRT tiap tahunnya. ${ }^{2}$ Angka tersebut termasuk tinggi, belum lagi jika mengingat masih ada korban lain yang belum berani melaporkan kasus KDRT yang dialaminya.

\footnotetext{
1 UNICEF, "Domestic Violence Against Women and Girls," Innocenti Digest, No. 6, June, Florence, Italy: United Nations Children's Fund, Innocenti Research Centre, 2000.

2 Agung Ismiyanto, "Rifka Annisa Catat Rata-Rata Ada 300 Laporan Kekerasan Perempuan di DIY," diakses pada $\quad 3$ November 2017,
}

Pasal 3 Ayat 3 Undang-Undang Nomor 39 Tahun 1999 tentang Hak Asasi Manusia menyebutkan "Setiap orang berhak atas perlindungan hak asasi manusia dan kebebasan dasar manusia, tanpa diskriminasi." Perintah untuk melindungi orang yang lemah, menegakkan keadilan, kesetaraan, dan larangan berbuat kerusakan juga menjadi ketentuan/perintah dalam Islam, sebagaimana firman Allah dalam AlQur'an surah Al-Qasas: 77 menyebutkan “... Berbuat baiklah (kepada orang lain) sebagaimana Allah telah berbuat baik kepadamu, dan janganlah kamu berbuat kerusakan di muka bumi. Sungguh, Allah tidak menyukai orang-orang yang berbuat kerusakan." ${ }^{3}$ Sesuai dengan spirit yang terkandung dalam ayat di atas, maka penanganan kasus kekerasan terhadap perempuan bisa dikategorikan sebagai dakwah bilhal, yaitu dakwah yang dilaksanakan dengan tindakan nyata. Mengakhiri kekerasan terhadap siapa pun termasuk terhadap perempuan merupakan misi universal kemanusiaan yang sesuai dengan nilai-nilai substansial Islam.

Kekerasan terhadap perempuan terjadi di mana saja dan kapan saja. Jenis-jenis kekerasan bisa terjadi di rumah/keluarga, lingkungan pekerjaan, tempat hiburan, sekolah, kampus, dan lain-lain. Kekerasan terhadap perempuan yang terjadi di lingkungan rumah/keluarga/rumah tangga inilah yang kemudian dikenal dengan kekerasan dalam rumah tangga (KDRT).

http://jogja.tribunnews.com/2017/03/08/rifkaannisa-catat-rata-rata-ada-300-laporan-kekerasanperempuan-di-diy/

${ }^{3}$ Aljamil: Al-Qur'an Tajwid Warna, Terjemah Per Kata Terjemah Inggris (Bekasi: Cipta Bagus Segara Bekasi, 2012), 394. 
Di bawah ini akan dipaparkan hasil survei yang dilakukan oleh Badan Pusat Statistik (BPS) bekerja sama dengan Kementerian Pemberdayaan Perempuan dan Pelindungan Anak tentang kasus kekerasan terhadap perempuan dan anak di Indonesia, survei ini mereka namakan Survei Pengalaman Hidup Perempuan Nasional (SPHN) tahun 2016. Berdasarkan jenis-jenis kekerasan yang dialami oleh perempuan diperoleh data bahwa persentase perempuan usia 15-64 tahun pernah/sedang menikah yang mengalami kekerasan fisik atau seksual dilakukan oleh pasangan pada tahun 2016 tercatat sebesar 18,3\%, sedangkan kekerasan fisik dan/atau seksual terhadap perempuan dalam 12 bulan terakhir oleh pasangan prevalensinya hanya sekitar $5 \% .{ }^{4}$ Prevalensi kekerasan dalam rumah tangga (KDRT) yang menimpa perempuan yang pernah/sedang menikah tercatat lebih tinggi pada kekerasan fisik dibandingkan kekerasan seksual. Prevalensi kekerasan fisik terhadap perempuan semasa hidup oleh pasangan tercatat sebesar 12,3\%, sedangkan prevalensi kekerasan seksual tercatat sebesar 10,6\%. Akan tetapi prevalensi kekerasan seksual $(3,8 \%)$ dalam 12 bulan terakhir oleh pasangan lebih tinggi daripada kekerasan fisik $(1,8 \%)^{5}$

Sedangkan kekerasan dalam rumah tangga yang berbentuk kekerasan emosional dihitung merujuk kejadian semasa hidup menunjukkan prevalensi yang tinggi yakni 20,5\%. Artinya 1 dari 5 perempuan

4 Kementerian Pemberdayaan Perempuan dan Pelindungan Anak kerja sama dengan Badan Pusat Statistik, Statistik Gender Tematik - Mengakhiri Kekerasan Terhadap Perempuan Dan Anak di Indonesia, 34. Catatan Tahunan Komnas Perempuan 2016.

5 Kementerian Pemberdayaan Perempuan dan Pelindungan Anak kerja sama dengan Badan Pusat pernah/sedang menikah pernah mengalami kekerasan emosional semasa hidupnya. Selanjutnya, prevalensi kekerasan emosional yang dihitung dalam 12 bulan terakhir tercatat sebesar 7,5\%. Atau dengan kata lain 1 dari 13 perempuan yang pernah/sedang menikah pernah mengalami kekerasan emosional dalam 12 bulan terakhir. ${ }^{6}$

KDRT dalam bentuk kekerasan ekonomi, di antaranya seperti perempuan tidak diperbolehkan bekerja untuk menghasilkan uang, penghasilannya diambil oleh suami/pasangan dan/atau suami/pasangan menolak memberikan uang belanja rumah tangga padahal dia memiliki uang. Data prevalensi kekerasan ekonomi dalam rumah tangga antara lain: hampir 25\% (1 dari 4) perempuan pernah/sedang menikah pernah mengalami kekerasan ekonomi semasa hidupnya, demikian juga terdapat fakta bahwa 1 dari 11 perempuan (9\%) mengalami kekerasan ekonomi dalam 12 bulan terakhir. $^{7}$

Kekerasan pembatasan aktivitas mencakup empat aspek pembatasan yaitu suami/pasangan selalu ingin tahu keberadaannya setiap saat, suami/pasangan mengharuskan ia meminta izin jika ingin keluar rumah, suami/pasangan marah jika berbicara dengan lelaki lain, dan suami/pasangan selalu curiga bahwa ia tidak setia. Persentase perempuan yang mengalami minimal satu pembatasan

Statistik, "Persentase perempuan usia 15-64 tahun pernah/sedang menikah yang mengalami kekerasan fisik atau seksual dilakukan oleh pasangan tahun 2016." Statistik Gender Tematik - Catatan Tahunan Komnas Perempuan 2016, 34.

${ }^{6}$ lbid., 35.

7 lbid., 36. 
aktivitas tersebut di atas semasa hidupnya oleh suami/pasangan di Indonesia mencapai sekitar 42 persen. Jika dihitung berdasarkan kekerasan pembatasan aktivitas yang dialami dalam 12 bulan terakhir, prevalensinya tercatat sebesar $32,4 \%$. Dari empat jenis kekerasan pembatasan aktivitas, "selalu ingin tahu keberadaanya setiap saat" menempati persentase tertinggi, diikuti oleh pembatasan berupa "harus meminta izin suami jika ingin keluar" baik untuk kejadian semasa hidupnya maupun dalam 12 bulan terakhir. ${ }^{8}$

KDRT di atas tidak hanya melanggar HAM sebagaimana yang disinggung dalam tulisan ini sebelumnya, tetapi juga berdampak buruk terhadap perempuan korban KDRT. Secara umum dampak kekerasan terhadap perempuan dapat dilihat dari berbagai aspek seperti kesehatan mental, perilaku, kesehatan fisik, ekonomi, dan sosial. Terkait dengan kesehatan mental, perempuan yang mengalami kekerasan mungkin dapat mengalami berbagai gangguan mental seperti depresi, kehilangan rasa percaya diri, malu, trauma, stres, merasa terasing, suka marah, kesepian, dan merasa tak berguna atau tanpa harapan dalam hidupnya. Terkait tingkah laku, kekerasan terhadap perempuan dapat memengaruhi perilaku perempuan seperti berpikir atau melakukan tindakan untuk mengakhiri hidupnya, penyalahgunaan alkohol dan obat-obatan terlarang, serta makan tidak teratur. Permasalahan kesehatan fisik yang umumnya terjadi akibat kekerasan terhadap perempuan antara lain mencakup cedera fisik berupa luka, patah tulang, atau lebam,

8 lbid., 37

9 UNICEF 2000; WHO 2012; Johnson, dan kawankawan, 2008. sakit punggung, sakit kronis, sulit tidur, tekanan darah tinggi, keguguran kandungan, dan sebagainya. ${ }^{9}$

Dari sisi ekonomi kekerasan terhadap perempuan dapat berakibat pada kesulitan ekonomi, seperti kehilangan pendapatan karena kehilangan pekerjaan, biaya perawatan kesehatan, dan biaya-biaya lain yang mungkin harus dikeluarkan. Sementara itu, dampak sosial dari kekerasan terhadap perempuan yang mungkin langsung dirasakan oleh perempuan dalam berbagai aspek. Stigmatisasi dan diskriminasi mungkin bisa terjadi pada perempuan yang mengalami kekerasan. Selain itu, perempuan korban kekerasan juga mungkin bisa merasa asing atau khawatir dalam berhubungan dengan teman atau keluarga, atau bahkan terisolasi dari keluarga dan teman-temannya.

Kemudian dampak lain yaitu dampak psikis, dalam tulisan Gelfland, dkk. dikatakan bahwa ibu yang mengalami depresi menunjukkan tingkat afeksi yang rendah terhadap anak mereka. ${ }^{10}$ Mereka akan memilih untuk melakukan sesuatu yang dianggap tidak menyulitkan mereka, misalnya tidak mau mengurus anak-anak mereka. Bahkan ekstremnya, perilaku mereka justru berpotensi akan membahayakan anaknya. Contohnya seperti yang disebutkan dalam penelitian yang dilakukan oleh Bellani, responden perempuan korban KDRT yang mengalami tekanan secara psikologis, dalam memperlakukan anaknya mereka cenderung membentak, memarahi, mencubit, bahkan

10 Gestadela Bellani, Nu'man, dan M. Thobagus "Sensitivitas Keibuan pada Perempuan Korban KDRT". Jurnal Psikologika Universitas Islam Indonesia Yogyakarta, Vol. 19, No.1, (2014), 64. 
mengabaikan anak mereka ketika sulit diatur. Hal tersebut tentu sangat memengaruhi tumbuh kembang anak. Sehingga, perempuan korban KDRT yang tidak diberikan penanganan yang tepat akan menyumbangkan generasi bangsa yang tidak berkualitas.

Mengingat dampak buruknya seperti hal di atas, maka perempuan korban KDRT sangat membutuhkan berbagai intervensi atau bantuan dari berbagai pihak, baik masyarakat, lembaga-lembaga, maupun pemerintah agar mereka dapat keluar dari jeratan KDRT dan mereka bisa mengembalikan fungsi sosialnya sebagaimana manusia normal lainnya. Prijono S. Onny dan Pranarka menyebutkan bahwa serangkaian upaya perlu dilakukan pada kelompok yang tertinggal atau rentan karena gangguan fungsi sosialnya agar mereka mempunyai kemampuan dan keberdayaan dalam menentukan pilihan hidupnya adalah disebut pemberdayaan. ${ }^{11}$ Sehingga, upaya-upaya pemberdayaan pada perempuan korban KDRT sangatlah dibutuhkan.

Diupayakannya pemberdayaan terhadap perempuan korban KDRT sebenarnya tidak hanya berdampak pada individu perempuan itu sendiri, melainkan juga pada masyarakat. Hal tersebut dikarenakan perempuan memiliki peranan penting di dalam masyarakat. Kontribusi utama perempuan kepada masyarakat adalah memberikan

11 Onny S. Prijono dan Pranarka. Pemberdayaan Masyarakat: Konsep Pembangunan yang Berakar pada Masyarakat. (Jakarta: Bappenas, 1996), 55.

12 Kartini Kartono. Psikologi Wanita: Mengenal Wanita Sebagai lbu dan Nenek. (Bandung: CV. Mandar Maju, 1992), 24-25.

13 Lihat Komisi Nasional Anti Kekerasan terhadap Perempuan, "Catatan Kekerasan terhadap Perempuan pendidikan anak di lingkungan keluarga. Ibu memiliki kontribusi penting dalam mencetak generasi yang berkualitas. Sebagaimana yang disebutkan oleh Kartini Kartono, bahwa fungsi seorang ibu dalam mendidik anaknya adalah menghasilkan manusia-manusia yang berbudaya, bersusila (mampu memberdayakan hal-hal yang baik dan benar), dan mewariskan nilai-nilai keagamaan pada anak mereka. ${ }^{12}$

Penanganan kasus KDRT telah banyak diinisiasi oleh lembaga swadaya masyarakat (LSM) yang concern terhadap pendampingan perempuan korban KDRT. ${ }^{13}$ Salah satunya adalah Rifka Annisa yang ada di Yogyakarta. Lahirnya Rifka Annisa, atau yang berarti "Teman Perempuan", adalah berangkat dari kepedulian terhadap nasib perempuan akibat dari budaya patriarki yang melemahkan posisi perempuan di masyarakat yang kemudian mengakibatkan perempuan sangat rentan mengalami kekerasan. Nama Annisa sendiri yang melekat pada nama Rifka Annisa diambil dari Al-Qur'an, yang berarti perempuan. Hal ini menunjukkan sebenarnya lembaga ini pun memiliki semangat yang sama dengan AlQur'an yang mengajarkan tentang penghormatan dan perlindungan terhadap perempuan sebagaimana tercantum dalam surat An-nisa ayat 19: "Hai orang-orang beriman, tidak halal bagi kamu mempusakai wanita dengan jalan paksa dan janganlah kamu menyusahkan mereka karena hendak mengambil kembali sebagian dari apa yang

tahun 2019," sebanyak kurang lebih 70 (tujuh puluh) LSM dan lembaga pemerintah di Indonesia yang menangani kasus kekerasan perempuan berpartisipasi memberikan kontribusi data atas kasus-kasus kekerasan perempuan yang mereka tangani di wilayah mereka masing-masing. 
telah kamu berikan kepadanya, terkecuali bila mereka melakukan pekerjaan keji yang nyata. Dan bergaullah dengan mereka secara patut. Kemudian bila kamu tidak menyukai mereka, (maka bersabarlah) karena mungkin kamu tidak menyukai sesuatu, padahal Allah menjadikan padanya kebaikan yang banyak." $^{14}$

Oleh karena itu, tujuan Rifka Annisa adalah berusaha menghapus ketimpangan tersebut dengan meningkatkan keberdayaan dari perempuan korban kekerasan. Maka dalam menyelesaikan permasalahan KDRT di masyarakat, Rifka Annisa berusaha untuk membantu para perempuan korban KDRT agar bisa terlepas dari berbagai bentuk kekerasan dari suaminya dan memiliki kesadaran yang tinggi untuk tidak lagi mendapatkan kekerasan. ${ }^{15}$ Adapun dipilihnya Rifka Annisa sebagai LSM perempuan yang dikaji dalam tulisan ini karena tingginya kasus-kasus KDRT yang mereka tangani. Selama kurun waktu 20122016 (lima tahun), terdapat 1.109 kasus kekerasan rumah tangga (kekerasan terhadap istri) yang sudah ia tangani. ${ }^{16}$ Ini menunjukkan bahwa Rifka Annisa memiliki komitmen yang cukup tinggi dalam menangani perempuan korban KDRT baik dari segmen manapun, dari berbagai kalangan usia, anak-anak, remaja, dewasa, sudah menikah dan tidak. Adapun angka kekerasan terhadap rumah tangga ini merupakan angka tertinggi dibandingkan angka kekerasan perempuan dalam kasus pacaran, trafficking, pelecehan seksual, atau pemerkosaan.

${ }^{14}$ Aljamil: Al-Qur'an Tajwid Warna, Terjemah Per Kata, Terjemah Inggris (Bekasi: Cipta Bagus Segara Bekasi, 2012), 80.

15 Rifka Annisa Women's Crisis Center, Annual Report 2013, (Yogyakarta: Pusat Pengembangan Sumber Daya
Fokus tulisan ini adalah mengkaji bagaimana model intervensi komunitas Rifka Annisa dalam melakukan pemberdayaan perempuan korban kekerasan dalam rumah tangga di Yogyakarta pada tahun 20122016.

Beberapa kajian mengenai Rifka Annisa telah banyak dilakukan, salah satunya artikel yang berjudul Peran Pendamping dalam Pemberdayaan Perempuan Korban Kekerasan Seksual di LSM Rifka Annisa karya Puthut Probolaksono, Strategi Coping Korban Kekerasan dalam Pacaran di Rifka Annisa Women Crisis Center Yogyakarta karya Yogi Abdul Aziz, dan Analisis Faktor Eksternal dan Faktor Internal Kettner dalam Organisasi Layanan Sosial Rifka Annisa Women Crisis Center karya lin Rizkiyah, ketiga kajian di atas menggunakan Rifka Annisa sebagai objek penelitian, sama dengan tulisan ini, namun perbedaannya pada subjek kajian ketiganya berbeda. Sedangkan pada studi intervensi komunitas, terdapat pula studi yang dilakukan oleh Arifiartiningsih dengan judul Pemberdayaan Mantan Buruh Migran Perempuan (BMP) di Desa Lipursari, Kecamatan Leksono, Kabupaten Wonosobo. Persamaannya dengan studi ini adalah sama-sama mengkaji intervensi komunitas dengan objek penelitiannya sama-sama perempuan, namun perbedaannya ada pada objek yang dikaji secara spesifik yaitu perempuan sebagai buruh migran pada studi Arfiartiningsih, sedangkan studi ini perempuan korban KDRT.

Untuk Penghapusan Kekerasan Terhadap Perempuan Rifka Annisa, 2013). 5.

16 Rifka Annisa Women's Crisis Center, "Data Kasus terhadap Perempuan Anak Tahun 2012-2017," diakses 29 Desember 2019, Pukul 09.15, www.rifkaannisa.org/id/layanan/data-kasus. 
Dari hasil penjaringan data pada pengindeks daring Google Cendikia, kajian model intervensi komunitas masih jarang dilakukan, kalau boleh dikatakan masih sedikit. Jika pun ada, yang membahas intervensi komunitas secara khusus dalam konteks penanganan masalah kekerasan terhadap perempuan, atau spesifik KDRT masih belum ditemukan. Alasan lain dari intervensi komunitas ini, bagi mereka yang bergelut dalam bidang pekerjaan sosial, pendampingan pada masyarakat Islam, pemberdayaan masyarakat Islam (PMI) penting untuk mengetahui kisah intervensi komunitas masyarakat Islam, khususnya dalam konteks studi ini intervensi komunitas pada muslimah (ibu rumah tangga) yang menjadi korban KDRT. Sebab penanganan intervensi terhadap komunitas khusus, yaitu perempuan korban KDRT tentu juga membutuhkan intervensi khusus. Bagi mereka yang concern terhadap bidang ini, baik kalangan praktisi maupun akademisi barangkali bisa menengok dan belajar dari kisah intervensi Rifka Annisa dalam mendampingi komunitas perempuan korban KDRT.

\section{Model Intervensi Komunitas}

Adapun penggunaan teori model intervensi komunitas dicetuskan oleh Rothman dan Tropman. ${ }^{17}$ Pertimbangan penggunaan teori ini, teori model intervensi komunitas compatible dalam mendeskripsikan realitas pendampingan yang dilakukan oleh Rifka Annisa terhadap para perempuan korban

17 Rothman dan Tropman dalam Idi Isbandi Rukminto Adi, Intervensi Komunitas dan Pengembangan Masyarakat sebagai Upaya Pemberdayaan Masyarakat, Edisi Revisi 12, (Jakarta: Rajawali Grafindo Persada, 2008), 89-98.
KDRT. Mereka menyusun model intervensi komunitas berdasarkan tiga prinsip model strategi intervensi, antara lain: perencanaan sosial; (2) Pengembangan masyarakat lokal; dan (3) Aksi Sosial. Teori ini banyak digunakan dalam mendeskripsikan fenomena model intervensi berbagai subjek pemberdaya masyarakat sebagaimana yang menjadi fokus tulisan ini juga.

Adapun ketiga model model intervensi di atas, dibedakan berdasarkan atas dua belas kategori yang masing-masing dapat dijelaskan sebagai berikut: ${ }^{18}$ pertama, kategori tujuan intervensi terhadap komunitas/kelompok sasaran; (a) model perencanaan sosial, bertujuan pemberian tugas yang harus diselesaikan oleh klien/kelompok sasaran (task goal); (b) model pengembangan masyarakat lokal bertujuan mengembangkan kapasitas dan pengintegrasian unsur-unsur sosial masyarakat, oleh karena tujuannya demikian maka subjek pemberdaya lebih menekankan process goal daripada task goal; (c) model aksi sosial, bertujuan untuk mengubah sumber daya dan relasi kekuasaan, perubahan institusi dasar, sehingga ia lebih menekankan by process goal sekaligus task goal.

Kedua, kategori struktur komunitas dan kondisi permasalahan yang digunakan oleh subjek; (a) model perencanaan sosial cenderung memilih masalah yang hendak diselesaikan adalah masalah khusus tertentu, seperti masalah kemiskinan, ${ }^{19}$ kekerasan dalam rumah tangga, minimnya akses modal para pengusaha kecil

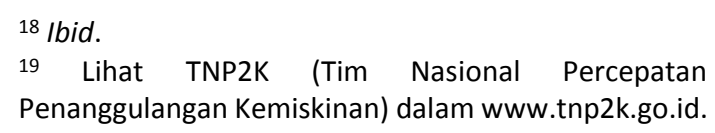
Penanggulangan Kemiskinan) dalam www.tnp2k.go.id. 
perempuan, ${ }^{20}$ penyandang difabilitas,${ }^{21}$ dan lain-lain, yang tanpa dibatasi oleh komunitas dalam wilayah tertentu saja, tetapi sepanjang ada anggota masyarakat yang miskin, perempuan (istri) yang mengalami KDRT, perempuan pengusaha kecil, penyandang difabilitas, di mana pun mereka maka menjadi kelompok sasaran dari organisasi yang menerapkan model intervensi komunitas ini; (b) model pengembangan masyarakat lokal sebaliknya, mengatasi seluruh persoalan yang dialami oleh komunitas dalam wilayah tertentu, baik terkendala oleh masalah sosial apa pun itu, baik kemiskinan dan difabilitas, ${ }^{22}$ kemiskinan dan kekeringan, ${ }^{23}$ dan lain-lain; (c) sedangkan aksi sosial memahami masalah komunitas sebagai korban dari ketidakadilan, tekanan dari pihak tertentu.

Ketiga, strategi dasar dalam melakukan perubahan; (a) model perencanaan sosial mengutamakan langkah-langkah pengumpulan data sebagai pijakan untuk menyusun rencana pemecahan masalah, dengan kata lain, seorang perencana akan mengumpulkan fakta-fakta mengenai masalah yang dihadapi dulu sebelum mereka memilih tindakan rasional yang bisa direkomendasikan, implikasinya keterlibatan kelompok sasaran dalam mencari pemecahan akan rendah sekali; (b) sebaliknya model pengembangan masyarakat lokal, sangat menekankan keterlibatan kelompok sasaran dalam mengambil keputusan atas masalah yang mereka hadapi (process goal), subjek

\footnotetext{
20 Lihat PEKKA (Pemberdayaan Perempuan Kepala Keluarga) dalam www.pekka.or.id., lihat juga ASPPUK (Asosiasi Pedamping Perempuan Usaha Kecil) dalam www.asppuk.or.id.

21 Lihat YPK Bali dalam www.ypkbali.org.id.

22 "Sepenggal Asa Kampung Tunagrahita," diakses 2 Desember 2019, Pukul 21.00, www.cnnindonesia.com
}

pemberdaya akan melibatkan warga seluas mungkin dalam menentukan pemecahan masalah yang mereka hadapi; (c) model aksi sosial menggunakan strategi pengorganisasian diri dan membentuk aksi massa untuk memberikan tekanan/pressure balik terhadap kelompok tertentu yang selama ini menekan mereka, seperti pemberian bantuan aksi sosial tertentu (aksi hukum) yang dapat mengembalikan ketidakadilan yang diderita kelompok sasaran akibat pelaksanaan hukum tertentu.

Keempat, karakteristik taktik dan teknik perubahan; (a) model perencanaan sosial lebih mengandalkan teknik-teknik pengumpulan data, analisis data, kemudian merumuskan pemecahan masalahnya, mengapa demikian? Karena perumusan alternatif pemecahan masalah lebih banyak tersentralisasi di tangan perencana, maka perencana membutuhkan data-data yang cukup sebagai pijakan untuk menentukan solusi apa yang terbaik untuk ditawarkan kepada klien; (b) sebaliknya taktik dan teknik yang digunakan dalam model pengembangan masyarakat lokal lebih mengandalkan kesepakatan dari berbagai pihak, karena memang mengandalkan proses diskusi untuk pencapaian kesepakatan dari berbagai unsur pihak masyarakat; (c) sedangkan model aksi sosial lebih mengandalkan teknik pengorganisasian massa dan pergerakan massa untuk memengaruhi proses politik, untuk menuntut ketidakadilan yang dialami

dan "Lentera Indonesia-Kisah Eko Mulyadi Pemerhat Tuna Grahita di Ponorogo," Net.Documentary, diakses 18 April 2018, Pukul 18.00

${ }^{23}$ Lihat pemberdayaan kampung Nglanggeran dalam gunungapipurba.com 
massa karena perbuatan/keputusan dari pihak tertentu.

Kelima, orientasi terhadap struktur kekuasaan; (a) pada model perencanaan sosial, pihak-pihak yang masuk dalam kategori pihak yang berwenang, seperti aparat pemerintahan desa, kota, aparat kepolisian, pengadilan, dan sebagainya diposisikan sebagai sponsor/pendukung dari pihak perencana sosial. Para perencana yang menentukan pemecahan masalah, namun dalam merealisasikan pemecahan masalah ini ia membutuhkan dukungan (sponsor) dengan berbagai pihak, seperti aparat hukum (kepolisian dan pengadilan, atau bahkan lembaga bantuan hukum), pihak aparat pemerintahan lokal (RT, RW, atau kepala desa, dan lain-lain), dan lain-lain sebagai sumber-sumber pendukung atas realisasi solusi yang telah diambil oleh subjek intervensi; (b) sedangkan model pengembangan masyarakat lokal sebaliknya, pihak berwenang diposisikan sebagai partner/kolaborator yang bekerja bersamasama memecahkan masalah yang dihadapi oleh komunitas lokal tersebut; (c) model aksi sosial, memosisikan pihak berwenang sebagai pihak yang menjadi target dari aksi sosial yang mereka adakan, karena ada asumsi ketidakadilan dari pihak kelompok tertentu (entah dari pihak pemerintah sendiri atau pun nonpemerintah) diketahui dan disahkan oleh pihak penguasa.

Keenam, media perubahan; (a) pada model perencanaan sosial, media perubahan mereka adalah lobi-lobi para sponsor agar bersedia mendukung/turut serta andil dalam membantu mewujudkan pemecahan masalah yang telah diambil; (b) model pengembangan masyarakat lokal, menggunakan kelompok-kelompok diskusi yang berfungsi sebagai media merumuskan pemecahan masalah, misalnya: agar masyarakat dapat menentukan mengambil keputusan tindakan apa yang harus diambil, sangat ditentukan pemahaman masyarakat atas masalah-masalah yang mereka hadapi, aset-aset apa saja yang mereka miliki, dan lan-lain, sehingga masyarakat bisa memutuskan pemecahan apa yang terbaik. Hal di atas dapat dicapai, jika ada kelompokkelompok diskusi kecil yang bisa memediasi tumbuhnya pemahaman-pemahaman masyarakat atas masalahnya; (c) model aksi sosial, media perubahannya adalah menciptakan pengorganisasian dan pergerakan massa untuk memengaruhi proses politis.

Ketujuh, peran praktisi; (a) model perencanaan sosial, para praktisinya berperan sebagai seorang pakar (expert) yang menentukan pemecahan masalah apa yang harus diambil, sedangkan; (b) model pengembangan masyarakat lokal, para praktisinya berperan sebagai seorang pemungkin (enabler) yang membantu masyarakat agar memiliki kapasitas dalam merealisasikan kebutuhan-kebutuhan mereka, atau memecahkan masalahmasalah mereka; (c) model aksi sosial, peran praktisinya berperan sebagai seorang advokat dan aktivis, yang membantu kelompok sasaran menyampaikan aspirasi atas nasib ketidakadilan yang mereka alami.

Kedelapan, batasan penerima layanan; (a) sebagaimana yang telah disebutkan pada item kedua, bahwa pada model perencanaan sosial, kelompok sasaran tidak dibatasi kesatuan lokal, melainkan dibatasi oleh satu kesatuan masalah khusus/masalah tertentu yang menjadi concern penanganan dari subjek pemberdaya, seperti Rifka Annisa 
yang fokus penanganan masalahnya adalah kasus perempuan yang mengalami kekerasan, baik kekerasan dalam ranah rumah tangga/keluarga, publik (sekolah, tempat kerja, dan lain-lain), dan sebagainya, dan keseluruhan para perempuan tersebut dapat tinggal di mana pun mereka. Sehingga penanganan atas kasus ini, tidak dibatasi pada komunitas perempuan di satu kesatuan wilayah tertentu saja, melainkan bisa berasal dari berbagai wilayah dusun, desa, dan lainlain. Jika perempuan mengalami kekerasan tersebut cukup banyak dalam kesatuan geografis tertentu bisa jadi juga menjadi bagian dari kelompok sasaran dari lembaga ini, kelompok sasaran dari model ini diposisikan sebagai klien (pihak yang harus diberi pemecahan masalahnya); (b) sebaliknya model pengembangan masyarakat lokal, kelompok sasaran yang ditangani terikat dalam satu kesatuan geografis; (c) sedangkan pada model aksi sosial, kelompok sasaran mereka adalah komunitas tertentu yang membutuhkan layanan (hukum) tetapi tidak terjangkau/ditolak mendapatkan layanan tersebut, para subjek pemberdaya yang menggunakan model ini lebih melihat kelompok sasaran sebagai partisan (pihak yang harus diorganisasi/dimobilisasi untuk melakukan aksi tertentu guna mengembalikan ketidakadilan yang mereka alami).

Kesembilan, asumsi kepentingan kelompokkelompok dalam suatu komunitas. Dalam melakukan intervensi komunitas, subjek pemberdaya akan berhadapan dengan berbagai macam kelompok-kelompok sosial yang memiliki kepentingan yang berpotensi mendukung sehingga bisa menjadi partner/kolaborator atau sponsor dalam upaya intervensi pada kelompok sasaran, namun ada juga kelompok yang memiliki kepentingan yang berbeda, dan bertentangan dengan kelompok sasaran tersebut. Di bawah ini, kekhasan dari masing-masing model intervensi, antara lain: (a) dalam perencanaan sosial, kepentingan kelompok-kelompok sosial yang ada dalam lingkungan sekitar komunitas klien/subjek dianggap tidak ada kepentingan yang saling bertentangan, mereka bahkan bisa menjadi support group/sponsor atas gagasan pemecahan masalah yang dirancang oleh subjek pemberdaya; (b) sedangkan dalam model pengembangan masyarakat lokal, kelompok-kelompok yang ada dalam komunitas bekerja sama memecahkan masalah bersama-sama dengan dipandu/distimulasi oleh subjek pemberdaya; (c) dalam model aksi sosial, kelompok-kelompok sosial memiliki kepentingan yang berbeda-beda, bahkan ada yang bertentangan. Sehingga kadangkala cara-cara koersif, konflik menjadi perlu dilakukan untuk memperjuangkan kepentingan dari kelompok yang mengalami subordinat.

Kesepuluh, asumsi mengenai penerima layanan; (a) dalam model perencanaan sosial, penerima layanan/kelompok sasaran dipandang oleh subjek pemberdaya sebagai konsumen yang tinggal menerima hasil jadi solusi yang diberikan. Kelompok sasaran menjadi pihak yang pasif, tidak ikut terlibat dalam kegiatan merumuskan solusi, karena solusi tersebut dirancang oleh tenaga ahli terlatih. Tenaga ahli ini bekerja berbasis pada data-data yang telah dikumpulkan, dan dari data-data tersebut mereka merancang solusinya; (b) sedangkan dalam model pengembangan masyarakat lokal, kelompok sasaran merupakan subjek yang dianggap penting, aset yang berharga, masukan, dan 
pendapatnya penting, mereka dilibatkan secara penuh dalam merumuskan pemecahan masalah; (c) pada model aksi sosial, kelompok sasaran diasumsikan sebagai korban dari ketidakadilan struktur/sistem.

Kesebelas, konsepsi mengenai peran penerima layanan, pada item ini sangat berhubungan erat dengan item kesepuluh; (a) oleh karena kelompok sasaran diasumsikan merupakan konsumen/pengguna manfaat, maka peranperan yang diberikan adalah penerima pelayanan (recipient), artinya klien aktif mengonsumsi (menggunakan) layananlayanan yang diberikan; (b) sebaliknya model pengembangan masyarakat lokal, kelompok sasaran berperan aktif partisipatif dalam merumuskan berbagai kebijakan untuk mereka sendiri, mereka bersama berusaha belajar dan mengembangkan diri.

Keduabelas, pemanfaatan intervensi komunitas, (a) model perencanaan sosial, mencari tahu para pengguna manfaat tentang layanan yang mereka butuhkan, serta memberi tahu para pengguna manfaat tentang pilihan solusi yang ada; (b) sedangkan model pengembangan masyarakat lokal, mengembangkan kapasitas komunitas untuk mengambil keputusan bersama, serta membangkitkan rasa percaya diri akan kemampuan masingmasing anggota masyarakat; (c) model aksi sosial, pemanfaatan intervensi komunitas dengan cara meraih kekuasaan sesungguhnya bagi kelompok sasaran yang selama ini dianggap sebagai korban dari ketidakadilan struktur, dan memutuskan cara-cara meraih kekuasaan tersebut

24 Isbandi Rukminto Adi. Intervensi Komunitas dan Pengembangan Masyarakat Sebagai Upaya dilakukan dengan membangkitkan rasa percaya diri partisipan akan kemampuan mereka.

\section{Metodologi}

Sedangkan metode kajian yang digunakan adalah metode library research, yaitu metode kajian suatu realitas dengan menggunakan pustaka/literatur sebagai sumber utama/primer dalam mengkaji realitas tersebut. Sebagaimana disebutkan di atas, bahwa kajian mengenai model intervensi komunitas yang dilakukan oleh Rifka Annisa mengandalkan laporan tahunan, hasil reportasenya dan riset Rifka Annisa yang relevan. Adapun dokumen yang digunakan sebagai sumber data utama antara lain dokumen Laporan Tahunan (Annual Report) tahun 2012 - 2016, dokumen Gerakan Sosial Menuju Penghapusan Kekerasan terhadap Perempuan Laporan Refleksi Sepuluh Tahun Perjalanan Rifka Annisa, buku berjudul Kekerasan terhadap Perempuan karya Rifka Annisa, Buletin "Rifkamedia" dengan beberapa volume, dan lain-lain.

Istilah intervensi komunitas dapat ditemukan dalam beberapa literatur, walaupun penggunaan istilah ini berbedabeda. Seperti Midgley menyebutnya sebagai intervensi sosial. intervensi sosial menurutnya adalah upaya perubahan yang terencana dari pelaku perubahan kepada sasaran perubahan guna meningkatkan taraf hidup masyarakat ${ }^{24}$. Sedangkan Isbandi menyebutkan bahwa intervensi sosial adalah upaya untuk memperbaiki keberfungsian sosial para sasaran perubahan. Salah satu

Pemberdayaan Masyarakat. (Jakarta: Rajawali Pers, 2013), 42. 
sasaran perubahan adalah berada pada level komunitas. Selanjutnya Isbandi pun menggunakannya dengan istilah dengan intervensi komunitas. ${ }^{25}$ Adapun pengertian intervensi komunitas sendiri dalam tulisan ini adalah suatu bentuk campur tangan lembaga Women Crisis Center-Rifka Annisa berupa pendampingan/pemberdayaan pada kelompok sasaran tertentu, yaitu para perempuan yang menjadi korban KDRT.

\section{LSM Rifka Annisa Yogyakarta}

Rifka Annisa yang berarti "Teman Perempuan" adalah organisasi non pemerintah yang berkomitmen pada masa penghapusan kekerasan terhadap perempuan. LSM yang berlokasi di Jalan Jambon IV, Kompleks Jatimulyo Indah, Yogyakarta ini didirikan pada tanggal 26 Agustus 1993, atas dasar inisiatif oleh beberapa aktivis perempuan antara lain: yaitu Suwarni Angesti Rahayu, Sri Kusniyuniati, Latifah Iskandar, Desti Murdijana, Sitoresmi Prabuningrat, dan Musrini Daruslan. ${ }^{26}$ Gagasan pendirian organisasi ini muncul dari kepedulian dan keprihatinan yang mendalam pada kecenderungan budaya patriarkhi ${ }^{27}$ yang pada satu sisi memperkuat posisi laki-laki tetapi di sisi lain memperlemah posisi perempuan. Adanya persoalan kekerasan berbasis gender yang muncul di masyarakat tersebutlah yang kemudian mendorong

\footnotetext{
${ }^{25}$ Isbandi Rukminto Adi. Ilmu Kesejahteraan Sosial dan Pekerjaan Sosial: Pengantar pada Pengertian dan Beberapa Pokok Bahasan. (Jakarta: FISIP UI PRESS, 2005), 141-150.

26 Rifka Annisa Pusat Pengembangan Sumberdaya untuk Penghapusan Kekerasan terhadap Perempuan, "Sejarah Rifka Annisa," diakses 27 Juni 2019, Pukul 13.50, www.rifka-annisa.org/id/2013-10-04-07-0657/sejarah.

${ }^{27}$ Budaya Patriarkhi adalah sebuah sistem sosial yang menempatkan laki-laki sebagai sosok otoritas utama
}

Rifka Annisa untuk melakukan berbagai upaya dalam rangka penghapusan kekerasan terhadap perempuan.

Rifka Annisa memiliki visi, mewujudkan tatanan masyarakat yang adil gender yang tidak menoleransi kekerasan terhadap perempuan mulai prinsip keadilan sosial, kesadaran dan kepedulian, kemandirian, integritas yang baik dan memelihara kearifan lokal. Sedangkan misinya adalah mengorganisasi perempuan secara khusus dan masyarakat secara umum untuk menghapuskan kekerasan terhadap perempuan dan menciptakan masyarakat yang adil gender melalui pemberdayaan perempuan korban kekerasan, termasuk di dalamnya anak-anak, lanjut usia, dan difabel, meningkatkan kesadaran dan partisipasi masyarakat melalui pendidikan kritis dan penguatan jaringan. ${ }^{28}$

Sedangkan program Rifka Annisa lebih berbentuk layanan, antara lain konseling psikologis, konseling hukum, konseling lakilaki, Wisma Rifka Annisa (shelter house), dan support group (dukungan kelompok yang bersumber dari kerabat dekat korban atau sesama korban), dan lain-lain. Program layanan di atas berpijak pada kerangka kerja ekologis (ecological framework), artinya program-program kerja Rifka Annisa di atas berbasis pada perspektif 5 (lima) lingkaran konsentris penyebab kekerasan yang saling berhubungan satu dengan lainnya. ${ }^{29}$

yang sentral dalam organisasi sosial, sehingga laki-laki lebih banyak memiliki kuasa untuk mengendalikan. Sehingga bisa dikatakan bahwa kekerasan terhadap perempuan tersebut merupakan kekerasan yang berbasis gender.

28 Rifka Annisa Pusat Pengembangan Sumberdaya untuk Penghapusan Kekerasan terhadap Perempuan, "Visi Rifka Annisa," diakses 27 Juni 2019, Pukul 13.50, www.rifka-annisa.org/id/2013-10-04-07-06-57/visidan-misi.

$29 \mathrm{lbid}$. 
Lingkaran pertama, yang paling dalam pada kerangka ekologis adalah riwayat biologis dan personal yang dibawa masing-masing individu ke dalam tingkah laku mereka dalam suatu hubungan. Lingkaran kedua merupakan konteks yang paling dekat dimana kekerasan seringkali terjadi, yaitu keluarga atau kenalan dan hubungan dekat lainnya. Lingkaran ketiga adalah institusi dan struktur sosial masyarakat, baik formal maupun informal, dimana hubungan tertanam dalam bentuk pertetanggaan, di tempat kerja, jaringan sosial dan kelompok kemitraan. Lingkaran keempat adalah lingkungan ekonomi dan sosial, termasuk norma-norma budaya dan sistem hukum negara. Sedangkan lingkaran kelima, paling luar adalah lingkungan ekonomi dan sosial global, institusi dan struktur sosial global, jaringan global dan kelompok kemitraan bilateral atau multilateral.

Dari kerangka kerja ekologis itulah, akhirnya lahir program-progam intervensi komunitas pada perempuan korban kekerasan yang wilayah penanganannya tidak hanya meliputi konseling psikologis pada si korban, tapi juga konseling psikologis pada pelaku kekerasan (konseling laki-laki). Kemudian pada lingkaran konsentris ketiga, Rifka Annisa menjalin hubungan dengan keluarga dan para perempuan sesama korban KDRT sebagai support group, mengorganisir masyarakat sebagai elemen yang paling dekat dengan peristiwa KDRT dengan cara mendirikan CBCC (Community Based Crisis

${ }^{30}$ Rifka Annisa, Gerakan Sosial Menuju Penghapusan Kekerasan terhadap Perempuan Laporan Refleksi 10 tahun Perjalanan Rifka Annisa, (Yogyakarta: ReaD (Research, Education and Alternative Dialogue), 2003), 15 .

31 Rifka Annisa, "Pengorganisasian Masyarakat dan Advokasi," www.rifka annisa.org/id/magang-
Center)..$^{30} \mathrm{CBCC}$ ini merupakan media Rifka Annisa dalam mendampingi masyarakat agar komunitas dampingan mampu menjadi penggerak dalam upaya penghapusan kekerasan terhadap perempuan, Pendampingan ini dilakukan dengan tujuan agar masyarakat mempunyai kesadaran kesetaraan gender serta kesadaran untuk tidak melakukan kekerasan terhadap perempuan. ${ }^{31} \quad$ Adapun komunitas dampingan yang menjadi anggota CBCC antara lain: Paguyuban Bangun Tresno di Dusun Kadisoro, Gilangharjo, Pandak, Bantul serta kelompok Sida Rukun di Dusun Klisat, Srihardono, Pundong, Bantul, kemudian ada lagi Kelompok Mudi Lestarining Budi, Playen, Gunung Kidul, dan Huriya Maisya, Cokrodiningratan, Jetis, Yogyakarta. Usaha pencegahan KDRT pada pelaku juga dilakukan oleh Rifka Annisa dengan mendirikan Komunitas Laki-laki Peduli yang isinya mengedukasi laki-laki dalam mengelola hubungan dengan istri. ${ }^{32}$

Program penanganan kekerasan perempuan tidak hanya terbatas pada lingkaran konsentris ketiga saja, tetapi juga lingkaran keempat, yaitu lingkungan sosial hukum, pelibatan aset-aset kelembagaan sosial hukum masyarakat dengan pendirian Unit Pelayanan Perempuan Panti Rapih di rumah sakit, Unit Pelayanan Khusus 05 di Polsek Yogyakarta, serta bekerja sama juga dengan NGO (Non Governmental Group) lain untuk melakukan advokasi sehingga melahirkan Undang-Undang Penghapusan KDRT (UU PKDRT) Tahun 2004, Undang-Undang

penelitian/magang/item/48-pengorganisasianmasyarakat-dan-advokasi.

32 Defirentia One Muharomah, "Jatmiko: Cegah Kekerasan dengan Berbagi Kisah dan Berefleksi, Bukan Menggurui," diakses 17 Desember 2019, Pk. 07.00, www.rifka-annisa.org/id/berita/berita-umum. 
Pencegahan Tindak Pidana Perdagangan Orang (UUP-TPPO) Tahun 2007, Pendirian Pusat Layanan Terpadu Pemberdayaan Perempuan dan Anak (P2TP2A) pada tahun 2013, dan lain-lain, ${ }^{33}$ dan kemudian lingkaran kelima atau global dalam bentuk dukungan terhadap gerakan yang disebut CEDAW (Convention on the Elimination of All Forms of Discrimination Againts Women), yaitu sebuah perjanjian internasional yang ditetapkan oleh Majelis Umum PBB (Perserikatan Bangsa-Bangsa) mengenai penghapusan segala bentuk diskriminasi terhadap wanita dan Gender Mainstreaming (Pengarusutamaan Gender-2001). ${ }^{34}$

Ternyata Rifka Annisa selama ini tidak hanya terlibat dalam persoalan penanganan kasuskasus perempuan korban kekerasan dalam rumah tangga saja, tapi juga kekerasan di mana saja berada (tempat kerja, jalanan, sekolah, dan lain-lain). Rifka Annisa juga menangani kasus anak-anak korban kekerasan, perdagangan perempuan (trafficking), dan sebagainya. Rifka Annisa juga terlibat dalam berbagai penelitian mengenai pengalaman hidup laki-laki yang terkait dengan kekerasan, pengalaman hidup dalam kesehatan laki-laki dari sudut pandang laki-laki, dan sebagainya. ${ }^{35}$

\section{Profil Perempuan Korban KDRT}

Berdasarkan data yang diperoleh, karakteristik perempuan yang ditangani oleh Rifka Annisa periode Januari - Februari 2007,

\footnotetext{
33 Wakhit Hasim, "Gerakan Sosial Baru dan Rifka Annisa: Sebuah Refleksi", diakses 12 September 2019, Pk. 11.00, www.rifka-annisa.org/id.

34 Rifka Annisa Pusat Pengembangan Sumberdaya untuk Penghapusan Kekerasan terhadap Perempuan, "Visi Rifka Annisa," diakses 27 Juni 2019, Pk. 13.50. www.rifka-annisa.org/id/2013-10-04-07-06-57/visidan-misi.
}

sebanyak 30 perempuan yang mengalami kekerasan dalam periode tersebut berprofil sebagai berikut: (1) dari segi usia, perempuan korban KDRT tersebut berusia $30-39$ tahun sejumlah 12 orang (40\%), usia 40 - 49 tahun sejumlah 12 orang (40\%), kemudian berusia $20-29$ tahun ada 6 orang (20\%); (2) dari segi status pekerjaan, sebanyak 22 orang merupakan perempuan pekerja (73\%), dan tidak bekerja sebanyak 6 orang (27\%); (3) dari segi pendidikan, sebanyak 19 orang berpendidikan $\leq$ SLTA (63\%), > SLTA 11 orang (37\%); (4) dari segi status pernikahan, menikah sebanyak 20 orang (67\%), status cerai 10 orang (33\%); (5) dari segi waktu lamanya pernikahan, sebanyak 18 orang mereka telah menikah selama $\leq 10$ tahun menikah (60\%), dan sebanyak 12 orang telah menikah $>10$ tahun $(40 \%) .{ }^{36}$

Melihat dari profil di atas, ada fakta yang menarik bahwa korban KDRT justru mayoritas mereka adalah pekerja (73\%) dengan status pendidikan rendah $\leq$ SLTA (63\%), dan status pernikahan masih aktif sebanyak $67 \%$, dengan durasi lamanya pernikahan $\leq 10$ tahun (60\%).

\section{Intervensi Komunitas pada Perempuan Korban KDRT Oleh LSM Rifka Annisa Yogyakarta}

Sedangkan mekanisme penanganan perempuan korban KDRT yang dilakukan oleh Rifka Annisa bersifat terpadu dengan

\footnotetext{
35 Ibid., Rifka Annisa, "Visi Rifka Annisa," diakses 27 Juni 2019.

36 Richa Vinatalia, Carla R. Marchira, Mariyono Sedyowinarso, "Hubungan Kekerasan dalam Rumah Tangga pada Wanita yang Melakukan Konsultasi di Rifka Annisa Women's Crisis Center Yogyakarta," Jurnal Ilmu Keperawatan/No. 01/Januari/2009. 12-16.
} 
melibatkan berbagai unsur, antara lain unsur kesehatan (rumah sakit/puskesmas/klinik), hukum (kepolisian, pengadilan), keluarga (yang kemudian disebut dengan support group), konselor/konsultan psikologis untuk perempuan sebagai korban KDRT, dan konsultan psikologis untuk suami sebagai pelaku.

Berikut merupakan tahapan dalam pelaksanaan program pendampingan psikologis perempuan, ${ }^{37}$ pertama, tahap perencanaan. Setelah Rifka Annisa menerima pengaduan dari korban KDRT, klien akan diminta oleh pihak Rifka Annisa untuk menceritakan pengalaman kekerasan yang dialami korban kepada konselor. Selanjutnya klien akan diberikan selembar kertas untuk menggambar, hal tersebut disebut dengan tes grafis. Objek gambar yang biasanya diarahkan pada klien adalah seperti rumah, pohon, atau manusia. Lalu hasil gambaran tersebut akan diberikan kepada psikolog untuk dilakukan analisis psikologis agar pihak konselor dapat memahami kondisi klien. Hasil dari kegiatan pertama dan kedua di atas, maka konselor sebagai tenaga ahli akan memberikan pendampingan/konseling psikologis guna memulihkan psikologisnya. ${ }^{38}$

Kedua, tahap penyadaran. Setelah memahami permasalahan dari klien yang ditangani, maka kemudian konselor akan memberikan pengertian kepada klien mengenai kondisi yang dialaminya agar mereka bisa memahami dan menyadari situasi apa yang dialaminya, yaitu bahwa mereka adalah korban dari kekerasan yang

37 Lutfi Hariyanto, "Pelaksanaan Pendampingan Konseling di Rifka Annisa dalam pemberdayaan Perempuan Korban Kekerasan dalam Rumah Tangga (KDRT)," (Skripsi, Program Studi Pendidikan Luar Biasa Jurusan Pendidikan Luar Biasa Fakultas IImu dilakukan suaminya. Ketiga, tahap penerimaan. Setelah klien sadar akan keadaan yang dialaminya, konselor lantas memberikan motivasi agar klien bisa menerima keadaan yang dialaminya dan bahwa kejadian tersebut harus segera dilupakan. Keempat, tahap pemberdayaan. Pada tahap ini, konselor masih terus memberikan motivasi dan rasa percaya diri terhadap klien dalam skala yang tinggi. Klien akan diberdayakan melalu proses pengambilan keputusan untuk ke depannya, yaitu terkait kekerasan yang dialaminya dan kehidupan rumah tangga klien. Pada intervensi ini, Rifka Annisa menggunakan metode Casework, yaitu metode yang menekankan pada terciptanya hubungan (relasi) yang dekat antara klien dan konselor. Manfaat dari metode ini adalah agar pihak klien dapat merasa nyaman dan mengeksplor seluruh permasalahan yang dialami, sehingga pihak konselor juga dapat memahami sepenuhnya. Selain itu juga dapat membuat klien bersedia untuk mendengarkan dan melaksanakan saransaran yang diberikan Rifka Annisa padanya. Sehingga, tujuan dari konseling bisa tercapai dan klien menjadi lebih termotivasi serta mengembalikan kepercayaan dirinya lagi agar mereka dapat mengambil tindakan pengambilan keputusan untuk dirinya sendiri dan rumah tangganya.

Kelima, tahap terminasi. Tahap terminasi merupakan tahap akhir dari pelayanan pendampingan psikologis. Pada tahap ini, konselor secara perlahan-lahan akan mengurangi perhatiannya kepada klien. Hal tersebut bertujuan agar klien tidak merasa

Kependidikan Universitas Negeri Yogyakarta, 2016), 49-60.

38 Rifka Annisa, Gerakan Sosial Menuju Penghapusan Kekerasan, 20. 
tergantung lagi terhadap konselor dan memiliki kemandirian untuk menyelesaikan masalahnya. Namun, pada tahap ini, konselor tidak melepaskan kliennya begitu saja, melainkan ia akan terus memantau keadaan klien melalui telepon hingga dinyatakan bahwa mereka sudah mampu untuk mengambil keputusannya sendiri.

Keenam, pendampingan hukum (litigasi). Program pendampingan hukum merupakan layanan pendampingan yang diberikan kepada klien yang memutuskan untuk membawa kasus kekerasan yang dialaminya ke ranah hukum. Tujuan dari program ini adalah untuk memberikan pendampingan hukum, memantau kasus kekerasan yang dilaporkan mulai dari proses pelaporan hingga proses persidangan di pengadilan, memastikan bahwa korban mendapatkan hak-haknya secara hukum berkaitan dengan tindak kekerasan yang dialaminya, memberikan advokasi serta memberikan evaluasi terhadap proses penanganan kasus secara hukum. Adapun teknis-teknis dalam proses pelaksanaan pendampingan secara hukum adalah sebagai berikut: (a) klien datang/telepon/dijangkau melalui outreach atau sistem rujukan dari lembaga-lembaga terkait seperti kepolisian, untuk mengakses layanan Rifka Annisa; (b) klien diberikan informasi tentang layanan pendampingan hukum; (c) klien diberikan informasi tentang fungsi dari Rifka Annisa dalam penyelesaian kasus hukum mereka; (d) klien diberikan informasi tentang kedudukan kasus mereka secara hukum; (e) klien diberikan informasi tentang langkah hukum yang dapat ditempuh (beserta alternatif langkah penyelesaian lainnya); (f) dalam prosesnya, Rifka Annisa tidak memberikan pendampingan sepenuhnya pada seluruh klien. Namun hanya klien yang memang benar-benar membutuhkan saja yang akan didampingi secara menyeluruh, misalnya terkait biaya pelaporan. Salah satu kriterianya adalah klien yang tidak mampu secara sosial ekonomi, dalam proses hukumnya akan didampingi secara penuh. Sedangkan klien yang mampu, akan diarahkan untuk melaporkan proses hukum, namun konselor tetap melakukan pendampingan dan memantau proses hukum; (g) pendampingan klien selama proses persidangan saat klien dinilai tidak mampu menjalani sendirian; (h) pendamping harus melakukan koordinasi dengan pihak kejaksaan dalam penanganan kasus hukum; (i) dalam hal tuntutan jaksa yang terlalu ringan, pendamping harus membuat surat desakan; (j) pendamping harus berkoordinasi dengan majelis hakim sebelum proses persidangan; (k) dalam hal putusan hakim yang terlalu ringan, pendamping harus membuat surat desakan atau mengajukan banding. Selain itu, pendamping melakukan review dan membuat catatan tentang proses pendampingan hukum; (I) pendamping harus membuat catatan berkaitan dengan proses hukum yang dilalui masing-masing klien sebagai laporan dan untuk memantau kondisi terbaru.

Rifka Annisa tidak hanya memberikan intervensi kepada perempuan korban KDRT, melainkan juga pendampingan keluarga kepada pihak keluarga korban. Intervensi kepada keluarga korban ini tidak dilakukan pada setiap kasus KDRT yang mereka tangani, melainkan pihak keluarga yang memiliki kriteria sebagai berikut: (a) pihak keluarga klien menunjukkan sikap menjauh atau bersikap tidak peduli dengan persoalan yang dihadapi klien; (b) keluarga klien tidak memahami persoalan yang dihadapi klien 
karena persoalan pengetahuan dan paradigma; (c) keluarga klien mengancam klien secara fisik maupun psikis; (d) keluarga menolak keberadaan klien. Jika terdapat klien yang mengalami hal-hal di atas dalam keluarganya, maka hal-hal yang dilakukan untuk menangani masalah tersebut adalah: (a) sebelum dilakukan pendampingan keluarga, pihak pendamping akan menggali informasi-informasi tentang sikap keluarga klien; (b) berdasarkan data yang diperoleh, pendamping membuat surat undangan kepada keluarga klien untuk melakukan diskusi bersama dalam rangka penyelesaian kasus klien; (c) jika situasi tidak memungkinkan bagi keluarga klien untuk mengakses kantor Rifka Annisa, maka pendamping dapat melakukan home visite (mengunjungi rumah) pada keluarga klien; (d) dalam konseling keluarga, pendamping berfungsi sebagai fasilitator yang akan membantu keluarga dalam membicarakan persoalan klien; (e) jumlah pertemuan akan ditentukan sesuai kebutuhan Lembaga; (f) hasil dari konseling keluarga adalah klien dan keluarga menemukan bersama penyelesaian masalah.

Layanan berikutnya adalah support group merupakan salah satu layanan konseling bagi korban KDRT yang berfungsi sebagai tindak lanjut dari program pendampingan psikologis yang telah dijalani sebelumnya. Sehingga, klien yang diarahkan untuk mengikuti program support group ini adalah yang secara fisik sudah melalui pemulihan dan secara psikis tidak lagi ada rasa cemas atau trauma pasca kekerasan.

Para korban KDRT yang ada dikumpulkan dan difasilitasi agar mereka dapat saling berbagi rasa dan pengalaman kekerasan yang pernah dialami serta saling mendukung. Dan tujuan utama diadakannya program ini adalah agar klien dapat berdaya secara mental, bahwa mereka dapat memandang masa depan dan membuat keputusannya sendiri. Selain itu, Rifka Annisa juga mengharapkan agar dari kelompok yang didampingi tersebut dapat memunculkan agent of change bagi lingkungannya, sebab pandangan mereka tentang kekerasan telah terbuka sehingga juga akan turut serta menjadi subjek yang ikut dalam proses menghapuskan kekerasan. Pelaksanaan program ini adalah selama satu bulan. Dalam proses pelaksanaannya tersebut, fokus setiap pertemuan yang dilakukan berbeda-beda karena menyesuaikan dengan kebutuhan para anggota support group.

Kemudian programnya yang lain adalah konseling laki-laki. Kegiatan ini merupakan layanan konseling untuk perubahan perilaku. Layanan ini disediakan untuk laki-laki yang melakukan kekerasan dalam rumah tangga (KDRT). Layanan ini mucul karena banyaknya korban KDRT memilih untuk kembali kepada pasangannya sementara tidak ada intervensi apapun yang dilakukan terhadap pasangannya. Sehingga, rantai kekerasan yang dialami perempuan tidak akan terputus karena mereka akan kembali lagi dan mendapatkan perlakuan kekerasan dari suaminya. Tujuan dari program ini adalah untuk memberikan layanan konseling bagi klien laki-laki yang memiliki masalah dalam rumah tangga (sebagai pelaku) secara individu, membantu klien untuk mengenali perilaku kekerasan serta melakukan perubahan perilaku secara terstruktur. Tidak hanya itu, program ini juga diharapkan dapat membantu klien untuk memperbaiki hubungan dengan pasangan (istri) dan anak. 
Lebih jauh lagi, agar mencegah laki-laki menjadi pelaku kekerasan.

Teknis program ini adalah berangkat dari laporan korban KDRT yang datang kepada Rifka Annisa ataupun yang melaporkan pada pihak kepolisian. Pihak Rifka Annisa melakukan koordinasi atau kerja sama dengan pihak kepolisian agar mewajibkan pelaku kekerasan (suami), untuk melakukan konseling laki-laki. Lalu dari pihak kepolisian tersebut akan memberikan rujukan untuk menerima konseling laki-laki yang dilaksanakan oleh Rifka Annisa. Materi yang disampaikan pada peserta konseling adalah mengenai komunikasi dengan pasangan, mengelola amarah, peran aktif ayah, dan kekerasan berbasis gender. ${ }^{39}$

Program berikutnya adalah Meeting Couple. Layanan ini sengaja mempertemukan pasangan suami istri yang sedang mengalami pertengkaran dan rentan mengalami kekerasan oleh suaminya, sehingga menjadi sarana bagi pasangan tersebut untuk saling menyampaikan perasaan masing-masing. Hal tersebut diperjelas dengan penjelasan yang diberikan oleh Rifka Annisa dalam website-nya.

Meeting couple memang didesain untuk membantu pasangan mengungkapkan halhal yang selama ini tidak bisa dikomunikasikan dengan baik, baik itu masalah pengasuhan, pembagian peran dalam rumah tangga, komunikasi, seksualitas, apa yang disuka dan tidak disuka dari pasangan, dan persoalan lainnya sehingga mereka bisa saling mengerti dan

${ }^{39}$ Rifka Annisa Women's Crisis Center, Annual Report 2013, 18.

${ }^{40}$ Nurmawati, "Cerita Komunitas: Istri Pertama Saya HP", diakses 24 November 2017, www.rifka- memahami apa yang dirasakan pasangan yang selama ini tidak pernah diungkapkan dan tidak dikomunikasikan dengan baik. ${ }^{40}$

Dari penjelasan diatas, pemberdayaan yang dilakukan Rifka Annisa melalui program meeting couple ini sebenarnya berusaha untuk memperbaiki hubungan antara suami dan istri yang mengalami ketidakharmonisan serta berpotensi menjadikan perempuan atau pihak istri sebagai korban kekerasan. Sehingga, layanan ini menempati peran dalam upaya pencegahan atas kekerasan terhadap perempuan. Program ini juga didukung oleh program lainnya lewat pendirian Komunitas Laki-laki Peduli yang isinya mengedukasi para suami lewat forumforum diskusi seputar komunikasi dengan pasangan, mengelola amarah, mengelola ekonomi keluarga, mengelola rumah tangga agar berjalan harmonis, dan lain-lain. ${ }^{41}$

\section{Karakteristik Intervensi Komunitas Perempuan Korban KDRT Rifka Annisa}

Berdasarkan pemaparan data di atas, dapat dianalisis sebagai berikut pertama, tujuan intervensi komunitas pada perempuan korban KDRT yang ditangani oleh Rifka Annisa pada dasarnya berorientasi pada pemberian tugas yang harus diselesaikan oleh klien. Sebagaimana data yang telah dipaparkan di atas bahwa perempuan korban KDRT (selanjutnya akan disebut klien) diminta oleh pihak Rifka Annisa untuk menceritakan pengalaman kekerasan yang

annisa.org/id/berita/blog/item/508-istri-pertamasaya-hp

${ }^{41}$ Defirentia One Muharomah, "Jatmiko," diakses 17 Desember 2019, Pk. 07.00 
mereka alami kepada konselor. Ini adalah pemberian tugas pertama. Pemberian tugas kedua adalah klien akan diberi selembar kertas untuk menggambar, dan mereka diminta untuk menggambar objek antara lain rumah, pohon, atau manusia. Lalu hasil gambaran tersebut harus diserahkan kepada psikolog untuk dilakukan analisis psikologis agar pihak konselor dapat memahami kondisi klien.

Berkaitan dengan upaya konselor memberikan pemahaman dan penyadaran kepada klien mengenai situasi yang dialami, bisa diidentifikasi sebagai bentuk pemberian tugas juga kepada klien bahwa dalam sesi pemahaman dan penyadaran atas situasi yang dialami, diharapkan klien bisa menerima keadaan mereka dan mendudukkan permasalahan mereka dengan tepat (mampu menempatkan pengalaman kekerasan mereka sebagai masa lalu yang tidak boleh menghalangi/menghambat mereka untuk meneruskan langkah hidup selanjutnya). Dengan menerima keadaan mereka, mereka bisa diharapkan memiliki sikap yang tepat atas kondisi/situasi kekerasan yang menimpa mereka, dengan demikian mereka bisa diajak melakukan sesuatu yang bisa menghasilkan solusi atau jalan keluar atas masalah yang mereka alami.

Dilihat dari uraian di atas juga bisa dikatakan bahwa lebih menekankan hasil daripada proses. Artinya Rifka Annisa berharap kasuskasus kekerasan yang dialami oleh para klien akan menghasilkan suatu solusi/jalan keluar yang konkret bagi mereka, sehingga dapat dicegah kasus-kasus yang sama terulang kembali pada mereka. Sebagaimana mengacu pada teori intervensi komunitas, ditinjau dari tujuan intervensi komunitasnya,
Rifka Annisa menggunakan tujuan yang lebih mengacu pada tugas (task) dan berorientasi pada hasil.

Ditinjau dari asumsi masalah yang ditangani oleh Rifka Annisa, adalah masalah khusus tertentu, yaitu kasus kekerasan terhadap perempuan baik kekerasan yang terjadi di rumah tangga, tempat publik seperti sekolah, tempat kerja, tempat-tempat umum tertentu, seperti mall, dan sebagainya. Bahkan segmen masyarakat khusus yang ditangani oleh Rifka Annisa tidak hanya perempuan yang sudah berkeluarga (istri), tetapi juga pelajar, mahasiswi, perempuan pekerja, dan lainlain. Dalam penelitian ini kekerasan yang dikaji adalah kekerasan yang dialami oleh masyarakat dengan segmen khusus perempuan sebagai istri, dengan tanpa melihat latar belakang tempat tinggal, pendidikan, pekerjaan dan sebagainya.

Kemudian ditinjau dari strategi dasar dalam melakukan perubahan, Rifka Annisa berusaha untuk mengumpulkan faktafakta/data-data terlebih dahulu mengenai masalah yang dihadapi sebelum diputuskan bagaimana solusi yang tepat atas kasus kekerasan yang dialami oleh sang klien. Pengumpulan fakta-fakta dilakukan melalui mekanisme wawancara klien, terutama pada proses peristiwa kekerasan yang dialami sambil mempertimbangkan kesiapan psikologis klien. Dari fakta-fakta yang terkumpul tersebut, maka perencana akan mengambil tindakan lebih lanjut, misalnya melaporkan ke aparat hukum seperti kepolisian bila kekerasan bisa masuk dalam kategori pelanggaran hukum, mengantarkan klien ke pihak klinik/rumah sakit bila kekerasan membutuhkan perawatan fisik, dan seterusnya. Fakta-fakta tersebut 
menjadi pijakan utama untuk merumuskan solusi atas kekerasan yang terjadi pada diri klien.

Sedangkan taktik dan teknik intervensinya melibatkan tenaga ahli terlatih yang berjasa dalam mengumpulkan data/fakta-fakta kekerasan di lapangan yang tak lain dan tak bukan sumber primernya adalah si korban dan saksi bila ada saksi. Kemudian tenaga ahli jugalah yang akan menganalisis data/fakta yang telah dikumpulkan tersebut, kemudian barulah disusun rancangan solusi, baik atas perempuan/istri sebagai korban dan laki-laki/suami sebagai pelaku dengan menggunakan prinsip penanganan terpadu (melibatkan berbagai pihak).

Hal ini lurus dengan fakta yang ditemukan bahwa Rifka Annisa selalu mengupayakan untuk melakukan pengumpulan data terlebih dahulu terkait permasalahan korban-korban KDRT yang akan ditangani. Seperti pada program konseling yang dilakukan Rifka Annisa dalam mengintervensi korban KDRT adalah berupaya untuk mengumpulkan data-data terkait kekerasan yang dialami perempuan melalui cerita-cerita yang disampaikannya. Konselor akan menggali sebanyakbanyaknya terkait kondisi psikologis korban dan gangguan lainnya. Setelah itu akan dilakukan analisis terkait pemecahan masalah yang kemudian akan disarankan pada klien. Pada proses ini, semua keputusan diserahkan kepada klien, misalnya kesediaan untuk bercerai, menggugat suami, atau tetap bertahan dengan pernikahannya, dengan tetap mendapatkan pendampingan lebih lanjut.

Dari karakteristik yang disebutkan di atas, menunjukkan bahwa strategi dan teknik yang digunakan Rifka Annisa dalam menjalankan intervensinya pada perempuan korban KDRT adalah menekankan pada pengumpulan data dan penganalisisan faktafakta mengenai pengalaman kekerasan yang dialami tiap klien. Oleh karena itu, pengumpulan data yang lengkap dan penganalisisan yang akurat terhadap kasus KDRT yang dialami klien menjadi dasar untuk menerapkan intervensi.

Untuk memperoleh hal tersebut, Rifka Annisa banyak melakukan kerja sama dan melibatkan berbagai pihak terkait, misalnya pihak kepolisian, pengadilan, rumah sakit, dan masyarakat setempat. Contohnya seperti dalam proses konseling laki-laki yang mendapat rujukan dari pihak kepolisian. Pihak kepolisian akan memberikan arahan pada pelaku KDRT untuk mengikuti program konseling laki-laki setelah menerima laporan dari pihak korban dan memproses kasus KDRT. Termasuk pula dalam pendampingan keluarga korban, pihak konselor akan mengumpulkan terlebih dahulu fakta-fakta yang terjadi di lingkungan keluarga korban, apakah korban mengalami penolakan dan tidak didukung oleh keluarga. Kalau tidak ada dukungan maka tim support group akan mendatangi keluarga klien agar mereka bersedia memahami keadaan klien.

Dalam hal ini, dapat disimpulkan bahwa partisipasi atau peran dari klien tidak begitu menonjol dalam menentukan penyelesaian masalah yang mereka hadapi sendiri. Sehingga dalam pelaksanaan pemberian intervensi, pihak klien cenderung sebagai pihak penerima saran-saran dan mengikuti saran pemecahan dari tim ahli Rifka Annisa, misalnya seperti layanan konseling, shelter house (rumah aman), atau pendampingan litigasi/hukum. 
Dalam menyelesaikan kasus yang dialami klien, pihak Rifka Annisa bisa saja menetapkan penyelesaian berupa jalan damai antara suami dan istri melalui perundingan atau diskusi kedua belah pihak (mediasi) sebagaimana yang dilakukan dalam program meeting couple dan konseling laki-laki, atau juga menetapkan penyelesaian yang mengandung konflik atau pertentangan dengan pihak pelaku misalnya keputusan untuk melanjutkan perkara ke ranah hukum pidana atau memberikan saran bercerai kepada klien. Dan penetapan jalan penyelesaian tersebut tentu berangkat dari permasalahan masing-masing klien. Sebagaimana yang telah disinggung sebelumnya, karena persoalan tiap klien berbeda, maka penanganannya pastilah unik di setiap kasus.

Dengan dominannya peran Rifka Annisa dalam menangani kasus masing-masing kliennya, maka dapat dibaca pola peran Rifka Annisa yang menonjol adalah berperan penuh dalam mengumpulkan data dan menganalisis atas fakta/data, berperan penuh pula dalam membuatkan alternatifalternatif keputusan yang bisa/perlu diambil oleh sang klien. Rifka Annisa memainkan peranan dengan penuh pula dalam melobi pihak berwenang (pemerintah seperti aparat hukum kepolisian, pengadilan, dan lain-lain) agar bisa bekerja sama membantu pelayanan yang dibutuhkan klien. Sebagaimana yang dipaparkan dalam data di atas, bahwa pengadaan program konseling suami, meeting couple, support group, shelter house (rumah aman), pendampingan hukum/litigasi bagi klien tertentu yang membutuhkan, perawatan, dan pemulihan luka fisik akibat kekerasan fisik dari klinik/rumah sakit, dan lain-lain merupakan hasil keputusan penuh dari Rifka Annisa.

Dengan melihat uraian di atas, bahwa Rifka Annisa berhubungan erat pada pihak-pihak berwenang seperti Rumah Sakit, Aparat Kepolisian, Pengadilan, Lembaga Bantuan Hukum, untuk klien yang membutuhkan pendamping hukum (pengacara), maka bisa dilihat bahwa media perubahan yang digunakan oleh Rifka Annisa adalah media organisasi formal (pihak berwenang) yang ia lobi sedemikian rupa, sehingga bersedia membantu menangani kasus kekerasan yang dialami klien. Bekerja sama pula dengan NGO untuk mengesahkan UU Penghapusan KDRT (UUPKDRT), dan sejenisnya.

Dan otomatis bisa dilihat pula bahwa orientasi Rifka Annisa terhadap pihak pemegang kekuasaan dikonsepsikan sebagai sponsor (pendukung) dari masing-masing kasus yang ditangani oleh Rifka Annisa. Memang tidak semua kasus kekerasan yang ditangani selalu melibatkan pihak aparat pemegang kuasa, seperti aparat RT/RW, kepala desa, kepolisian, pengadilan, dan lainlain, tetapi dalam kadar tertentu ketika kekerasan sudah masuk dalam ranah pelanggaran hukum, maka Rifka Annisa memainkan peran penting dalam melibatkan berbagai pihak pemegang otoritas tersebut untuk mendukung kasus kekerasan yang dihadapi oleh kliennya. Termasuk pula saat klien mengalami kasus kekerasan namun tidak ada dukungan sama sekali oleh pihak keluarga korban, maka Rifka Annisa juga berperan penting untuk merangkul keluarga korban tersebut agar mau peduli dan mau berupaya memberikan perhatian, dukungan, dan motivasi pada korban, sehingga pemulihan dari masalah kekerasan tersebut dapat dilakukan. Melihat realitas ini, maka 
bisa dibaca pula bahwa kepentingan dari kelompok dalam satu komunitas merupakan satu kesatuan kepentingan, satu kemufakatan/kesepakatan kerja sama, bahu membahu dalam menolong korban/klien.

Dengan memandang betapa dominan/menonjolnya Rifka Annisa dalam menangani kasus kekerasan masing-masing kliennya, maka dapat disimpulkan pula bahwa klien diasumsikan sebagai konsumen/pengguna manfaat dari alternatif langkah solusi yang dibuat oleh Rifka Annisa. Klien tidak banyak terlibat dalam proses perumusan alternatif langkah solusi tersebut, klien mungkin bisa mengambil keputusan namun hanya sebatas memilih alternatif solusi yang ditawarkan. Hal ini disadari karena berkaitan dengan jenis masalah yang dihadapi oleh perempuan, yaitu KDRT yang berdampak pada tekanan jiwa, maka tidak memungkinkan klien merumuskan pemecahannya tanpa dibuatkan alternatifnya dari sang ahli.

Melihat dari keseluruhan kategori model intervensi di atas, maka bisa diketahui bahwa model intervensi Rifka Annisa menggunakan model perencanaan sosial. Namun berbeda dengan lembaga swadaya masyarakat/pemerintah yang menggunakan model intervensi yang sama, Rifka Annisa memiliki sisi keunikan tersendiri, jika tidak bisa disebut tidak murni melaksanakan model intervensi perencanaan sosial. Keunikan tersebut dapat dilihat, Rifka Annisa juga memanfaatkan aset-aset sosial yang tersebar di masyarakat. Seperti lembaga pemerintah, antara lain Kepolisian, Pengadilan, Rumah Sakit, keluarga, dan lain-

42 Wakhit Hasim, "Gerakan Sosial Baru dan Rifka Annisa: Sebuah Refleksi", diakses pada 12 September 2019, Pukul 11.00, www.rifka-annisa.org/id. lain, yang berpotensi menolong klien. Contoh bentuk pemanfaatan lembaga hukum, antara lain: pendirian Unit Pelayanan Khusus 05 di Polsek Yogyakarta yang memang sengaja diperuntukkan melayani perempuan korban KDRT, dengan pihak lembaga kesehatan, seperti rumah sakit, didirikanlah Unit Pelayanan Perempuan (Panti Rapih) di salah satu rumah sakit di Yogyakarta.

Tidak berhenti di situ saja, aset SDM, seperti masyarakat yang dapat menjadi sumber pelaporan terjadinya peristiwa kekerasan ia manfaatkan. Rifka Annisa pun akhirnya mendirikan CBCC (Community Based Crisis Center) sebagai bentuk usaha melibatkan masyarakat sebagai agen pelapor dan pencegah dini tindak kekerasan. Memberikan edukasi kepada pasangan dalam bentuk program Meeting Couple, dan laki-laki sebagai suami dalam bentuk pendirian Komunitas Laki-laki Peduli.

Rifka Annisa tidak hanya menjadi organisasi pelayanan perempuan korban KDRT, tetapi ia juga merupakan organisasi gerakan sosial, yang aktif melakukan kerja sama dengan NGO lain untuk melakukan advokasi sehingga melahirkan Undang-Undang Penghapusan KDRT (UU PKDRT) Tahun 2004, Undang-Undang Pencegahan Tindak Pidana Perdagangan Orang (UUP-TPPO) Tahun 2007, Gender Mainstreaming (2001), dan Pendirian Pusat Layanan Terpadu Pemberdayaan Perempuan dan Anak (P2TP2A) pada tahun 2013, dan lain-lain. ${ }^{42}$

\section{Kesimpulan}


Berdasarkan dua belas kategori/variabel model intervensi komunitas Rothman dan Tropman, maka dapat dideskripsikan bahwa model intervensi komunitas yang dilakukan oleh Rifka Annisa cenderung menggunakan model perencanaan sosial, hal ini dapat diketahui melalui 12 kategori dari model intervensi komunitas yang digagas oleh Rothman dan Tropman. Walaupun Rifka Annisa cenderung menggunakan model perencanaan sosial, namun ada sisi keunikan dari lembaga ini, ia tidak murni menerapkan model perencanaan sosial, di sisi lain ia juga menerapkan model intervensi pengembangan masyarakat lokal dengan cara pelibatan aset-aset kelembagaan sosial hukum masyarakat dengan pendirian Unit Pelayanan Perempuan Panti Rapih di RS, Unit Pelayanan Khusus 05 di Polsek Yogyakarta, sekaligus human asset lewat pendirian $\mathrm{CBCC}$, edukasi masyarakat lewat forum meeting couple untuk memperbaiki hubungan antar suami dan istri, serta pendirian Komunitas Laki-laki Peduli sebagai bentuk pencegahan dan solusi dini KDRT. Di samping itu, juga ditemukan sisi lain dari model intervensi komunitas, yaitu aksi sosial lewat aktif bekerja sama dengan NGO lain untuk menggolkan UU yang bertujuan mengeliminasi kekerasan dan pelayanan terhadap perempuan korban kekerasan.

Dari temuan-temuan di atas mengisyaratkan bahwa kedudukan sebenarnya intervensi komunitas adalah sebagai sebuah metode dalam menyelesaikan masalah yang muncul dalam masyarakat. Jika masalah bisa diselesaikan dengan syarat harus menempuh berbagai cara intervensi, maka subjek/lembaga perlu menempuh cara-cara tersebut agar masyarakat bisa menikmati kemanfaatan yang dihasilkan olehnya lewat program-programnya.

\section{Bibliografi}

Adi, Isbandi Rukminto. Intervensi Komunitas dan Pengembangan Masyarakat Sebagai Upaya Pemberdayaan Masyarakat. Jakarta: Rajawali Pers, 2013.

IImu Kesejahteraan Sosial dan Pekerjaan Sosial: Pengantar pada

Pengertian dan Beberapa Pokok Bahasan. Jakarta: FISIP UI PRESS, 2005.

Bellani, Gestadela, Nu'man, dan Thobagus M. "Sensitivitas Keibuan pada Perempuan Korban KDRT." Jurnal Psikologika Universitas Islam Indonesia Yogyakarta, Vol. 19, No.1 (2014). 6374.

Hariyanto, Lutfi. "Pelaksanaan Pendampingan Konseling di Rifka Annisa dalam pemberdayaan Perempuan Korban Kekerasan dalam Rumah Tangga (KDRT)," Skripsi, Program Studi Pendidikan Luar Biasa Jurusan Pendidikan Luar Biasa Fakultas IImu Kependidikan Universitas Negeri Yogyakarta, Yogyakarta, 2016.

Hasim, Wakhit. "Gerakan Sosial Baru dan Rifka Annisa: Sebuah Refleksi", September 12, 2019. www.rifka-annisa.org/id.

Ismiyanto, Agung. "Rifka Annisa Catat Rata-Rata Ada 300 Laporan Kekerasan Perempuan di DIY." November 3, 2017. http://jogja.tribunnews.com/ 2017/03/08/rifka-annisa-catat-rata-rataada-300-laporan-kekerasan-perempuan-di-diy/. 
Kartono, Kartini. Psikologi Wanita: Mengenal Wanita Sebagai Ibu dan Nenek. Bandung: CV. Mandar Maju, 1992.

Kementerian Pemberdayaan Perempuan dan Pelindungan Anak kerja sama dengan Badan Pusat Statistik, Statistik Gender Tematik - Mengakhiri Kekerasan Terhadap Perempuan Dan Anak Di Indonesia, 34. Catatan Tahunan Komnas Perempuan 2016.

Kementerian Pemberdayaan Perempuan dan Pelindungan Anak kerja sama dengan Badan Pusat Statistik, "Persentase perempuan usia 15-64 tahun pernah/sedang menikah yang mengalami kekerasan fisik atau seksual dilakukan oleh pasangan tahun 2016." Statistik Gender Tematik - Catatan Tahunan Komnas Perempuan 2016. http://www.komnasperempuan.go.id/read-news-catatan-tahunan-kekerasan-terhadapperempuan-2016.

"Lentera Indonesia-Kisah Eko Mulyadi Pemerhati Tuna Grahita di Ponorogo." April 18, 2018. Net.Documentary.

Muharomah, Defirentia One. "Jatmiko: Cegah Kekerasan dengan Berbagi Kisah dan Berefleksi, Bukan Menggurui." Desember 17, 2019. www.rifka-annisa.org/id/berita/berita-umum.

Nurmawati. "Cerita Komunitas: Istri Pertama Saya HP," November 24, 2017. www.rifkaannisa.org/id/berita/blog/item/508-istri-pertama-saya-hp.

Perempuan, Komnas. "Lembar Fakta Catatan Tahunan (CATAHU) Komnas Perempuan Tahun 2017 Labirin Kekerasan terhadap Perempuan: Dari Gang Rape hingga Femicide, Alarm bagi Negara untuk Bertindak Tepat, Jakarta, 7 Maret 2017." September 26, 2017. www.komnasperempuan.go.id//read-news-catatan-tahunan-kekerasan-terhadapperempuan-2017.

Prijono, Onny S. dan Pranarka. Pemberdayaan Masyarakat: Konsep Pembangunan yang Berakar pada Masyarakat. Jakarta: Bappenas, 1996.

Rifka Annisa. Gerakan Sosial Menuju Penghapusan Kekerasan terhadap Perempuan Laporan Refleksi 10 tahun Perjalanan Rifka Annisa, Yogyakarta: ReaD (Research, Education and Alternative Dialogue), 2003.

. Women's Crisis Center. Annual Report 2013. Yogyakarta: Pusat Pengembangan Sumber Daya Untuk Penghapusan Kekerasan Terhadap Perempuan Rifka Annisa, 2013.

. Pusat Pengembangan Sumberdaya untuk Penghapusan Kekerasan terhadap Perempuan. "Data Kasus Kekerasan terhadap Perempuan dan Anak tahun 2012-2017", Desember 29, 2019. www.rifka-annisa.org/id/layanan/data-kasus.

. "Visi Rifka Annisa." Juni 27, 2019, www.rifka-annisa.org/id/2013-10-04-0706-57/visi-dan-misi.

"Sejarah Rifka Annisa." Juni 27, 2019. www.rifka-annisa.org/id/2013-10-0407-06-57/sejarah.

"Pengorganisasian Masyarakat dan Advokasi." www.rifka annisa.org/id/magang-penelitian/magang/item/48-pengorganisasian-masyarakatdan-advokasi.

"Sepenggal Asa Kampung Tunagrahita." Desember, 2 2019. www.cnnindonesia.com.

UNICEF. "Domestic Violence Against Women and Girls," Innocenti Digest, No. 6, June. Florence. Italy: United Nations Children's Fund, Innocenti Research Centre, 2000. 
Vinatalia, Richa, Carla R. Marchira, Mariyono Sedyowinarso. "Hubungan Kekerasan dalam Rumah Tangga pada Wanita yang Melakukan Konsultasi di Rifka Annisa Women's Crisis Center Yogyakarta." Jurnal IImu Keperawatan/No. 01/Januari/2009. 12-16. 